症例

腹腔鏡下に胆囊胃瘦切除と胃内落下結石除去を行った 1 例

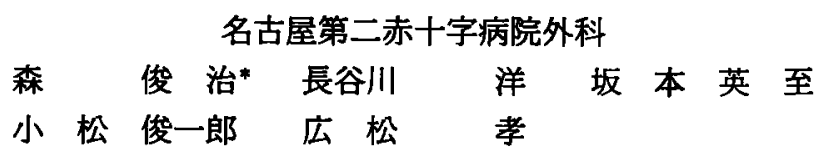

胆塞消化管瘦は胆石症の合併症のなかても比較的稀であるが，とくに胆事胃瘦の頻度 はさらに少ない，従来，胆茟消化管膺に対する腹腔鏡下手術は技術的難易度が高いため 禁忌とされていたが，手術手技と器具の進歩により腹腔鏡下手術完遂例の報告もみられ

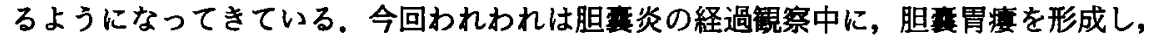
胃内に巨大結石が落下した症例に対し，腹腔鏡下に瘦孔を切除し，結石を除去すること ができたので報告する.

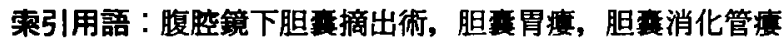

はじめに

胆篹消化管㿋は胆石症の稀な合併症であるが，その

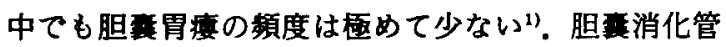
塿に対する腹腔鏡下胆衰摘出術は当初, 禁忌とされて いたが2), 現在では手技の向上と器材の進歩により, 適 応が拡大されつつある3). 今回, われわれは胆烡胃瘦と それによる巨大な胃内結石を合併した症例に対し，腹 胵鏡下手術を行い良好な経過を得たので報告する。

患者：67歳，女性.

症例

主訴：右季肋部痛。

家族歴：特記すべきことなし.

既往歴：栯尿病, 心筋梗塞.

現病歴：2001年 9 月より右季肋部痛が出現し, 近医 て胆石・胆重炎と診断され加療を受けていたが，症状 が持続するため，同年11月に当院へ紹介され，精查目 的で入院となった。

入院時現症：右季肋部に軽度圧痛を訆めた。

入院時血洨検査成縝：炎症所見はなく，胆道系醉素 の上昇も認めなかった，腫瘍マーカーも正常笵囲内で あった.

入院時腹部 CT 検査：胆集頸部に小結石が颉頓し，

2006 年 6 月 1 日受付 2006 年 7 月 5 日採用

・現：爱知会家田病院

〈所属施設住所〉

T466-8650 名古屋市昭和区妙見町 $2-9$
胆壁は嚄しく肥厚していた，胆豪内には径約 $3 \mathrm{~cm}$ の辺縁に石灰化を有する結石を認めた。胃幽門前庭部 は胆烡側へ引き寄せられ，胃壁も著明に肥厚していた (図 $1 \mathrm{a}, \mathrm{b}$ ).

内視鏡的逆行性胆管造影検査 (以下, ERC)：胆咅は 頸部までしか造影されず, 胆妻底部側には石灰化を伴 う結石を認めた（图 $1 \mathrm{c}$ ).

上部消化管内視篭検查 (以下, GIF) : 胃前庭部の後 壁に白苔を伴う潰瘍形成を認めた，以上により胆石・

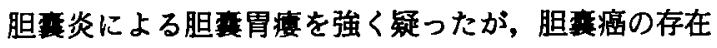
も否定できなかったため，血管造影検査および内視鏡 下超音波娭查を施行した。しかし，悪性病変を示唆す ろ所見は認めなかった。一週間後に再検した GIFで胃 前庭部の溃㾔は疫痕になっていた，以上より胆石・胆 害炎で胃瘦を形成し，瘦孔が自然閉鎖したと診断した。 心筋梗塞で抗凝固用を内服中であったこと, 瘦孔形成 後間もないため局所の炎症がまだ強く手術が困難であ ると予測されたため, 待機的に手術を行う方針で一旦 退院となった，退院後，特に症状はなかったが，3カ 月後に外来て CT 検査を再検したところ, 胆衰内にあ った結石が，胃内に落下していることが確認された。 また, 空気と同等の density を示す部分があり, 胆暴内 の空気の存在が示唆された（図 2 a).

上部消化管造影：胃内に落下した結石による透亮像 を認めた（図 2 b).

GIF：胃前庭部には胆毫胃瘦による深い謴演の形成 を認め, 胃内には結石を認めた（図 $2 \mathrm{c}$ ）。 


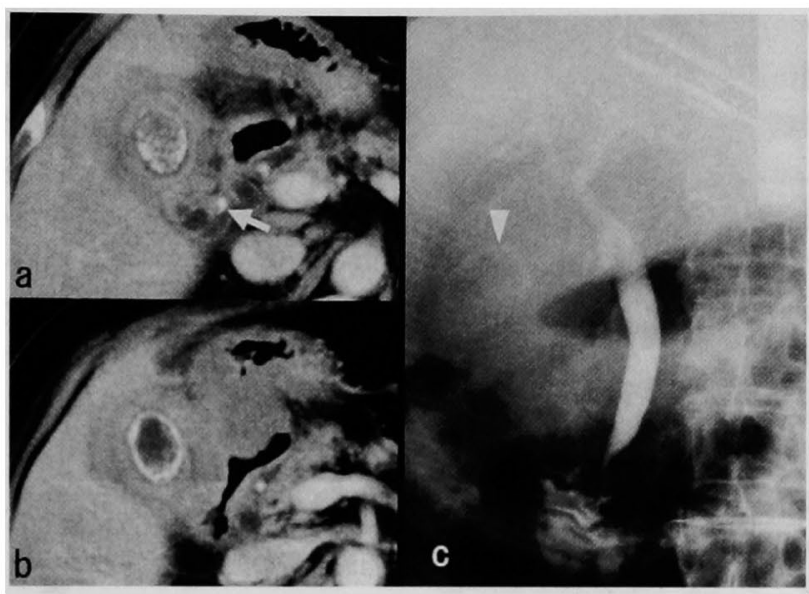

图 $1 \mathrm{a}, \mathrm{b}$ 入院時腹部 CT : 胆焦頸部に小結石が嵌頓し (矢印),

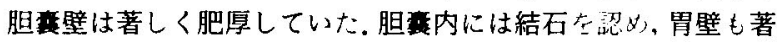
明に肥厚していた。

c ERC：胆莗は頸部までしか造影されず，胆塞底部側に石 灰を伴う結石（知頭）が認めた。

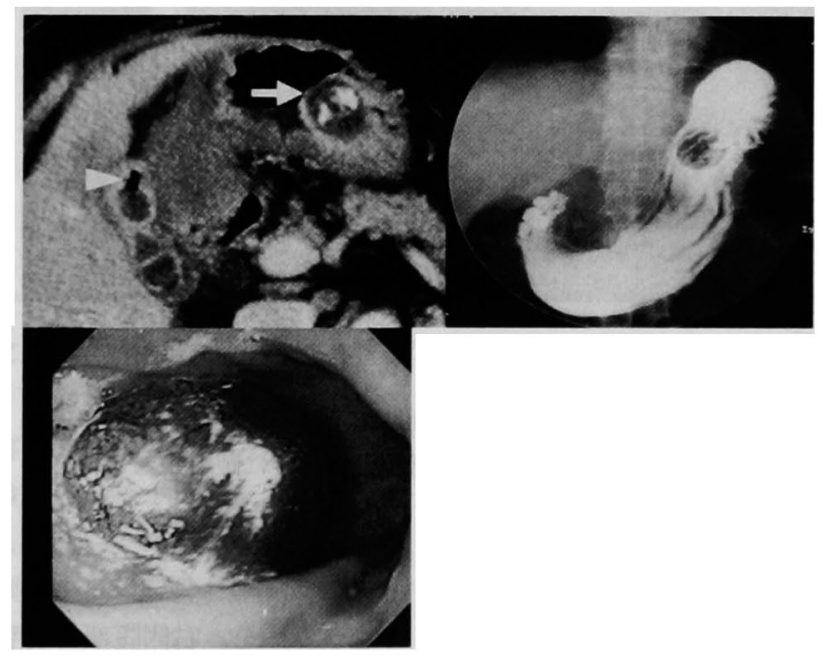

図 2 a 腹部 ('T：胃内に結石落下しており(矢印), 胆䨘内に air が存在した (矢頭)。

b 上部消化管造影， c GIF：胃内には落下した結石を梕 める。

胆塞炎により再び胃との間に瘦孔を形成し，胃内に 結石が落下したものと診断した.内視鏡下に胃内の結 石の摘出を試みたが，石が大きく回収不能であったた め，手術的に摘出する方針とした．胆震炎が高度で周 囲と強く癒着し手術は困難が予想されたが, 前回行っ た ERCで胆剚頸部が造影されているところから，頸
部で胆衰を処理できれば，腹腔鏡下での手術が可能と 判断し，腹腔鏡下手術を行う方針とした．として，胃 内の結石も同時に腹腔鏡下に胃を切開して摘出するこ とにした。

手術所見：臍下に開腹法で $12 \mathrm{~mm}$ トロッカーを挿入 し気腹後, 剣状突起下と右季肋部へ術者用に $5 \mathrm{~mm}$ 卜 


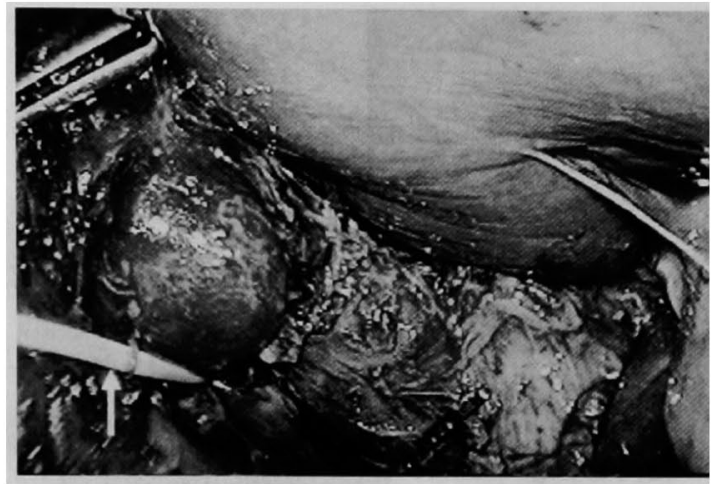

図 3 術中所見 1 : 胆重は著しく肥厚し, 周囲と強固に瘾

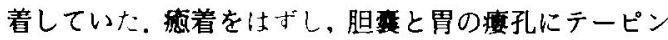
グした（知印）。

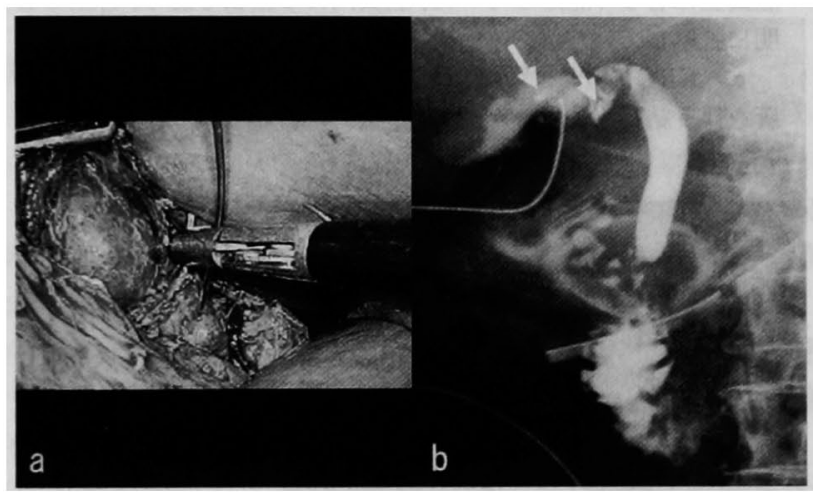

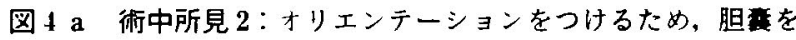
直接穿刺し胆道造影施行した。

b 徒中胆道造影所見：穿刺部はクリップ(矢印)を付けマー キングした胆奉頸部であり，総胆管と十分に距䧹があることを 確認した。

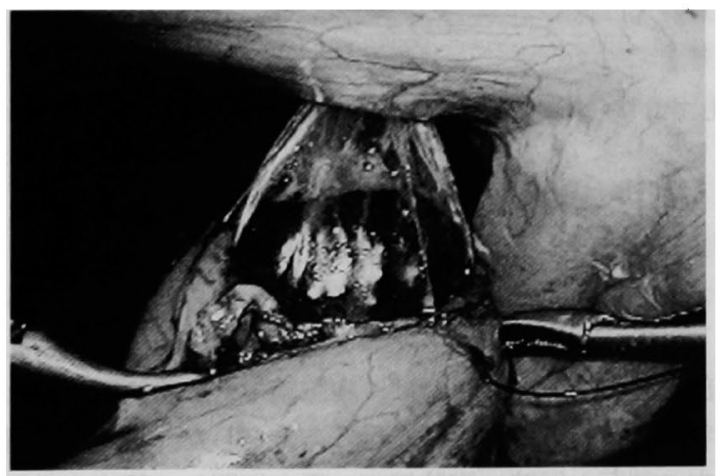

図5術中所見 3：胃切開部上り endopouch を用い，胃 内の結石を摘出した。

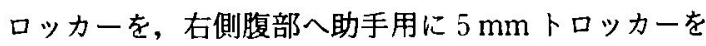
挿入した。左側腹部には結石を摘出するための $12 \mathrm{~mm}$ トロッカーを挿入した，腹腔内を観察すると胆菩は大 網および胃が強固に瘾着し一塊となっていた，胆烡周 用の痹着を切離し，胆裏と胃の間の瘦孔を確認し，テ 一ピングを行った(図3)。このテープを率引しつつ周

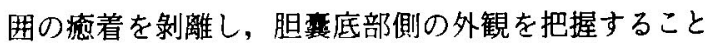
はできたが，胆真頸部付近は炎症が高度でオリエンテ ーションが全くつかないため，胆軎にクリップでマー

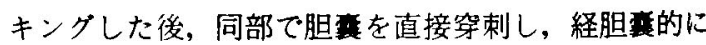
術中胆道造影を行った（図 $4 \mathbf{a}$ )。穿刺部は胆素頸部に あたり，胆萁管および総胆管とは十分に距離があった

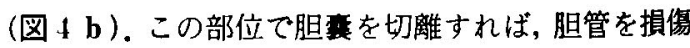


する危険性もないため, mucoclasis を行い, 断端は40吸収采で 4 針縫合した．胆旁を胆赛床より切離する と，胆谼は㿉孔で胃とつながるだけの状態となったた め, Endo-cutter を用い㿉孔を切離した. 続いて, 胃体 部前壁に 2 本の支持系をかけて胃壁を切開し, Endopouch を用い胃内の結石を回収した(図 5 ). 胃の切開 部はEndo-cutter を用いて閉鎖した。洗净して止血を 確認後，モリソン裔にペンローズドレーンを留置して 閉創し，手術を終了した。手術時間は 5 時間15分であ った.

術後経過：術後 2 日目より経口摄取を開始し, 術後 9 日目に退院とした。

\section{考察}

胆嚾結石症に対する標準術式として腹腔鏡下胆衰摘 出術が広く普及し，導入当初は禁忌とされた急性胆軎 炎やMirizzi 症候群など2)に対しても有用性が指摘さ れ，その適応は搪がりをみせている3141. 胆谼消化管度 に対する腹腔鏡下胆暴摘出術についても，報告例が散 見されるようになり，その有用性が確認されてい る

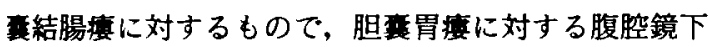
手術の報告例は，われわれが検索しえた限りでは，自 験例が本邦初と思われる。

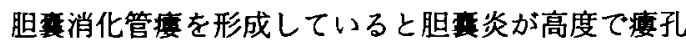
周囲は大網が被膜するなど強固に腎着しているため， この剩離に難渋することになる．胆重壁は著明に肥厚 している上, 萎縮も強く, 胆宾管や総胆管のオリエン テーションをつけるのも容易ではない.無理をすれば, 胆管損傷などを起こす危険性もあり十分な注意が必要 である。自験例においても瘦孔にテーピングをするこ

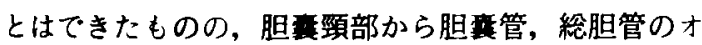
リエンテーションが全くつかなかったため, 胆意を直 接穿刺して術中胆道造影を行った。穿刺部が胆表頸部 であったため，従来のような胆毫管での処理にこだわ らず, mucoclasis を行っだ.解剖学的位置関倸を知る 上で，衍前にあらかじめ扱入した释買胆管ドレナージ チューブや術中の総胆萧的な造影が有用であったとす る報告もあり ${ }^{612 / 131}$ ，困難が予想される症例では試みて 良い方法であると思われた。また，術中所見によって は自験例のように mucoclasis を行うことになる場合 があり，日頃から腹腔鏡下での縫合結紮の技術を習得 しておく必要があると思われた ${ }^{914) 15) . ~}$

瘦孔の切離ついては End-cutterに上る一括処理 が, 多くの症例で試みられているがクー9112). 自験例にお
いても安全に㿉孔の処理が可能であった。

自験例では胃内の結石の摘出法が問題となった。一 つは瘦孔部を含め胃を切除し，ここから結石を摘出し た後に鏡視下で縫合するか, もう一つは瘦孔のみ stapler で切除し, 胃を別の部分で切開し, 結石除去後, stapler で閉鎖しょうというものである.われわれは後 者の方法を選択したが, その理由は瘦孔部は炎症が強 く，縫合を行うことが難しく，術後縫合不全を起こす 危険性が高いと考えたためである。結果的にも，瘦孔 の切除，胃切開部分の閉鎖ともに合併症を起こすこと なく経過し，最善の方法であったと考えている．

腹腔鏡下手術は手術手技や器具の進歩によりその適 応はさらに拡大している。諸家の報告が示すように胆 妻消化管㿉に対しても，比較的安全に行われるように なっており，今回では決して禁忌とは言えなくなって いる ${ }^{11}$.しかし,状況に応じて腹腔鏡下での結禁や縫合 などの手技の習熟が不可欠であり，容易に鏡視下手術 を行った場合, 胆管損傷などの合併症を起こす危険性 もあるため，慎重にアプローチ寸べきでる。この点 を十分考慮し手術を行えば,胆烡消化管瘦に対しても， 腹腔鏡下手術は良い適応になると考えられた。

\section{おわりに}

腹腔鏡下に治療しえた胃内結石を伴った胆軎男瘦の 1 例を経験したので報告した。腹腔鏡下手術の技術や 器具の向上はめざましく，胆售消化管瘦に対する鏡視 下手術も適応外とは言えなくなっており, 術者は腹腔 鏡下手術での操作に習熟しておく必要がある。

\section{文献}

1）福永裕充，青朴洋三，勝見正治他：特発性内胆计 瘦一自験例23例を含めた本邦症例の集計と文献的 考察一。臨外医会誌 $+3: 173-1 \%, 1982$

2）酒井 滋，山川達郎，石川泰郎：腹腔鏡下胆衰摘 出術の適応と限界. 日消外会誌 $24 ： 2635-2639$, 1991

3）長谷川洋, 坂本英至, 小松俊一郎他：腹腔鏡下胆 衰摘出術一適応と合併症の現況一.胆道 $18: 498$ $-506,2004$

4）長谷川洋, 小木曾清二, 粐山正人他：合流部結石 に対する内視鏡下手術.日内視鏡外会誌 $6: 232$ $-235,2001$

5）森值治, 早川直利，山本英夫地：腹腔鏡補助下 に治療した胆言十二指腸灌の 1 手術例. 中部外科 会総会号 $30 ： 55,1994$

6) Nuzzo G, Giuliante F. Tebala GD, et al : Lapar- 
oscopic management of cholecystogastric fistula. Endoscopy $29: 226,1997$

7）山本攻文，瀬戸島謙三，植木敏幸 他：腹腔鏡下に 手術し得た胆售十二指腸璂の 1 例。日内視鏡外会 誌 $4: 259-261,1999$

8）中沢和之，士橋重隆，中江尊義：腹腔鏡下に治療 し得た胆董結䁑瘦の 1 例. Gastroenterological Endoscopy $41: 199-202,1999$

9）仲地広美智，久保尚士，竹島義隆他：胆重消化管 㿋に対する腹胫鏡下胆衰摘出術. 日内視鏡外会誌 $4: 29-35,1999$

10) Prasad A, Kapur R: Cholecystogastric fistula : laparoscopic repair. Surgical laparoscopy, endoscopy \& percutaneous techniques $11: 277$ $-278,2001$
11) Angrisani L, Corcione F, Tartaglia A, et al: Cholecystoenteric fistula is not a contraindication for laparoscopic surgery. Surgical encoscopy $15: 1038-1041,2001$

12）文元雄一，宗田滋夫，根津理一郎：腹腔鏡下に切 除し得た胆辜小腸愺の 1 例. 日生病医誌 $29: 180$ $-185,2001$

13）森隆，松田忠和，岩藤浩典他：腹腔鏡下に処 置し得た胆重十二指腸瘦の 1 例. 日内視鏡外会誌 $8: 498-502,2003$

14）長谷川洋, 小木曾清二，粐山正人他：総胆管切開 一期的縫合. 臨外 $56: 327-331,2001$

15）長谷川洋：総胆管結石に対する腹腔鏡下手術 総 胆管切石術：一期的䋃合術.消外 $27: 965-972$, 2004

\title{
LAPAROSCOPIC SURGERY FOR CHOLECYSTOGASTRIC FISTULA WITH GALLSTONE IN STOMACH
}

\author{
Toshiharu MORI, Hiroshi HASEGAWA, Eiji SAKAMOTO, \\ Shunichiro KOMATSU and Takashi HIROMATSU \\ Department of Surgery, Nagoya Daini Red Cross Hospital
}

Cholecystoenteric fistulas have been reported to be a relatively rare complication of cholelithiasis, especially cholecystogastric fistula. At the beginning of the laparoscopic era, cholecystoenteric fistula was considered as an absolute contraindication for laparoscopic surgery. With development of surgical techniques and equipment, however, the number of cases in which cholecystoenteric fistula was treated laparoscopically have increased. We describe a case of laparoscopic surgery for cholecystogastric fistula with a gallstone in the stomach. 